\title{
Emerging of bio-nano composite gelatine-based film as bio-degradable food packaging: a review
}

\author{
${ }^{1}$ Tuan Zainazor, T.C., ${ }^{1}$ Fisal, A., ${ }^{2}$ Goh, E.G., ${ }^{3}$ Che Sulaiman, N.F. and ${ }^{1 *}$ Sarbon, N.M. \\ ${ }^{1}$ Faculty of Fisheries and Food Science, Universiti Malaysia Terengganu, 21030 Kuala Nerus, Terengganu \\ ${ }^{2}$ Faculty of Ocean Engineering Technology and Informatics, Universiti Malaysia Terengganu, 21030 Kuala \\ Nerus, Terengganu \\ ${ }^{3}$ Faculty of Business, Economics and Social Development, Universiti Malaysia Terengganu, 21030 Kuala \\ Nerus, Terengganu
}

\section{Article history: \\ Received: 7 November 2019 \\ Received in revised form: 12 January 2019 \\ Accepted: 23 January 2020 \\ Available Online: 19 \\ February 2020}

\section{Keywords:}

Nanoparticles,

Gelatine-based films,

Waste management

DOI:

https://doi.org/10.26656/fr.2017.4(4).365

\begin{abstract}
The increase in production of Municipal Solid Waste (MSW) from various sectors of the industry should be taken seriously globally. Efficient waste management has been promoted for a great and clean environment. The industry's by-products waste such as fish and poultry waste have been gaining researchers interest to seriousness converted it to a valuable commodity like alternative gelatine. Therefore, the review on current waste from industry in Malaysia and its impacts, potentially used of fish and poultry wastes as gelatine-based film using bio-nanotechnology approaches and business opportunities was discussed. Application of nanoparticles in food packaging is growing rapidly worldwide especially the development and implementation of bio-degradable packaging system that works against moisture, gas and microbial barrier is a very useful approach to achieve the mentioned function. Replacement of petroleum-based non bio-degradable plastics by bio-degradable packaging material significantly useful for future application in order to protect human health. This is because the major risk associated with nano-sized components is their potential opposing health effects due to its migration into food.
\end{abstract}

\section{Introduction}

Various industries rapidly expanding with the utilization of latest technology globally. However, there has been a lot of waste produced including agricultural and livestock waste. Sahu et al. (2017) reported that million tonnes of fish and prawn waste throughout the food chain is produced by fish and prawn processing industries. The waste such as fish intestine, gills, muscles, fat and prawn could be reused for other beneficial purposes. The reused principle normally refers to the repeated use of products or components for their intended purpose and the targets of reduction principle are to minimize of raw material use, energy input, and waste production (Ghisellini et al., 2016). Many studies have been conducted using this waste in the production of food packaging with the use of Nano-technology.

Recently, Nano-technology is the most recognized technology that shows the ability to synthesize new products with diverse applications and advantages. Application of nanoparticles in food packaging including nanoencapsulation, nanocomposite, nanoemulsions, edible nanocoatings and nano-coating materials (Sharma and Dhanjal, 2016). Moreover, biotechnological aid is applied to synthesize nanoparticles that helping by living entities such as bacteria (Farhoodi, 2016). The function of this technology that involved in food packaging, therefore, to protect food from damage and contamination, and extends the shelf life of food products, thus potentially reducing wasted food (Heller, 2017).

Sharma and Dhanjal (2016) stated that bionanotechnology proposals advanced anticipation in food packaging which will deliver the longer shelf-life, secure packaging and recover the quality of food. An intelligent food packaging can attentive on spoilage food whereas, during the active packaging, antimicrobials is added as preservatives into the food during the initiation of the spoilage (Duncan, 2011). Gelatine and silver nanoparticles and organo-clay that exhibit a significant activity of antimicrobial towards pathogenic bacteria. In addition, gelatine based nanocomposite films will benefit in competing and eliminating the bacterial invaders that can prolong the shelf life and improve the quality of food (Sharma and Dhanjal, 2016). 
Therefore, this paper presents a contemporary review of potential value added product that can be produced from industrial waste especially by- products from fish and poultry processing industry. The introduction of gelatin alternative from fish and poultry by-products offer a potential biodegradable film packaging which benefit to the mentioned industry in order to manage their waste. Thus, indirectly solve the environmental problems.

\section{Environmental impact}

\subsection{Solid waste generation in Malaysia Farm waste}

Municipal solid waste (MSW) generation increases steadily in Malaysia - as a response to the growing population (Abushammala et al., 2011). Based on 2017 estimation by CIA (2018), the country land area of $329,847 \mathrm{~km}^{2}$ is home to 31.38 million. The relative amount of MSW generation is strongly linked to the respective population of the states (Manaf et al., 2009). Among the 11 states in Peninsular Malaysia, the contribution of MSW is mainly from congested states like Selangor, Kuala Lumpur (capital of Malaysia) and Johor. Areas with fewer residents like Perlis, Melaka and Negeri Sembilan have the lowest figures.

The rate of MSW generation in 1990 for Malaysia was $0.7 \mathrm{~kg} /$ capita/day - slightly below that in developed countries like Singapore and the United Kingdom at 0.85 and 0.845 respectively (Eusuf et al., 2011). However, it was much higher than other countries like the Philippines at 0.5 . The Malaysia number soared to 1.5 in 2007 and is anticipated to increase further due to population growth and development (Periathamby et al., 2009). Waste management comes with an excessively high cost, comprising up to $50 \%$ of the municipal operating budget. The waste collection alone constitutes $70 \%$ of the budget, albeit collecting only $70 \%$ of total MSW (Johari, 2014). The situation would reach a tipping point should it continues. In curbing the issue, long ago the federal government passed a bill in 2007 to allow privatization of solid waste management company. A list of Malaysia transformation of solid waste management policies and plans was summarized by Razali et al. (2019).

The main contribution of MSW is activities of daily living, street cleaning, industrial production, construction works, landscape conservation, institutional and commercial activities (Johari, 2014). The residential waste alone amounts to $48 \%$ of gross MSW.

The waste generally comprises of food, paper, plastic, glass, metal, textiles and wood (Budhiarta et al., 2012; Fazeli et al., 2016; Zainu, 2017). Food represents as high as $45 \%$ of the total waste. Wet food waste from households constitutes $38.32 \%$ of the total food waste generated in Malaysia (Ministry of Housing and Local Government Malaysia, 2011). To minimise household food waste, Jereme et al. (2018) has identified a few solutions such as the formulation of households food wastes policies. The remainder of $60 \%$ of food waste originates from production to retailing (FAO, 2011). Due to high food waste percentage, MSW typically has high moisture content. For example, Kuala Lumpur waste contains 55\% moisture content by weight (Kathirvale et al., 2004). Other typical characteristics of the trash are high carbon and chlorine contents.

In the stages of agriculture, first is farming and husbandry activities, followed by food processing and manufacturing. The third stage is the retail at wet markets, grocers and supermarket. Lastly is at household, food service departments (restaurants, hospitality sector, cafe) and institutions such as education institutions, hospitals, prisons. As each point gives rise to food waste quantity, it is pertinent to consider revising the steps in bringing down the food waste.

At the present time in Malaysia, the majority of the waste is disposed and a minute portion recycled, composted, incinerated and used as landfill (Agamuthu, 2006). Landfill is generally categorized as inert, sanitary and unsanitary landfill (Agamuthu, 2006). Until 2002, $5 \%$ was subjected to recycling, $5 \%$ into sanitary landfills, and $90 \%$ as other disposal sites. Utilization of rubbish improved tremendously in 2006, with percentage increment of recycling to $5.5 \%$, composting $1.0 \%$, inert landfill $3.2 \%$, sanitary landfills $30.9 \%$ other disposal sites $59.4 \%$.

Albeit no latest statistics of waste reduction, it is believed that there is still a big gap before the achievement of the objectives of Malaysian Vision of 2020. Given the short span of one year before the deadline, it arduous to accomplish $22 \%$ recycling, $8 \%$ composting, increase incineration to $16.8 \%$, the inert landfill to be increased to $9.1 \%$, and aiming the sanitary landfill at $44.1 \%$ and a full closure of the unsanitary landfill. The most favoured options are to practice prevention, minimization, and reuse, rather than recycling, energy recovery, and land disposal (Lim et al., 2019).

\subsection{Environmental impacts of solid wastes}

Through the study of the life cycle inventory of open dumping and sanitary landfill starting from MSW collection in the residential area, Saheri (2011) has identified the severe environmental impacts of waste production, either directly or indirectly due to energy consumption, air emissions, and water discharge. Production and release of atmospheric carbon dioxide in 
energy consumption processes leads to global warming. Leachate - water discharged from unsanitary landfill has various toxicities and is harmful to the surrounding ecosystem. The high organic content of leachate has high biochemical oxygen demand that deprives oxygen from living organism. The lack of respiratory gas kills many lives. The absence of free oxygen also forces anaerobic reaction to occur and produces climate change byproducts like methane. Electricity generation produces toxic air such as hydrogen chloride, hydrogen fluoride, ammonia, nitrous oxides, sulfur oxides, all of which could cause acidification of rain, and aquatic eutrophication nitrogen and phosphorus (Abdul Aziz, 2007; Tonini et al., 2018). In energy utilization, heavy metals are emitted too (Abdul Aziz, 2007).

\section{Type of waste}

\subsection{Fish waste}

The fishing industries include any industry or activity that involves in taking, culturing, processing, preserving, storing, transporting, marketing or selling fish or fish products. Approximately 140 million tons of fish production, including aquaculture, are derives from a huge market share of international channels in which 110 million were for human consumption (Benhabiles et al., 2012). In addition, Food Agriculture Organization (FAO) also reported that aquaculture's contribution to total fish food supply grew at an average annual rate of 3.2\% from 1961 to 2013 (Ishak and Sarbon, 2018). This data showed that more than $60 \%$ of the industry's byproducts are fish wastes including head, skin, trimmings, fins, frames, viscera, and roe. These fish waste, especially from fish processing industries, are an important environmental contamination source. An important waste reduction strategy for the industry is the recovery of marketable by-products from fish wastes (Ishak and Sarbon, 2018).

Consequently, in the last two decades, fish byproducts have been gaining attention as a significant additional source of nutrition. For instance, a wide range of fish by-products is found such as oils, collagen, gelatine, hydrolysates, and bioactive peptides. Fish wastes, including frames, head, skin, scales, bone, and viscera, are used to produce protein hydrolysates (Ovissipour et al., 2009; Ishak and Sarbon, 2017; Rasli and Sarbon, 2019), gelatine (Cheow et al., 2007; Rosli and Sarbon, 2015; Rasli and Sarbon, 2019), bioactive peptides (Halim et al., 2016; Ishak and Sarbon, 2017; Halim and Sarbon, 2017; Halim et al., 2018) and collagen (Hamdan and Sarbon, 2019; Hadfi and Sarbon, 2019). Many studies have been reported on gelatine production from different part of fish by-products like from fish skin such as thornback ray (Lassoued et al.,
2014), shortfin scad (Rasli and Sarbon, 2018); from fish scales such as lizardfish (Saurida spp.) (Wangtueai and Noomhorm, 2008); from fishbone such as Freshwater Fish (Cirrhinus mrigala) (Chandra et al., 2013), Tigertoothed croaker (Otolithes ruber) and Pink perch (Nemipterus japonicus) (Koli et al., 2012).

\subsection{Poultry waste}

Recently, poultry waste especially chicken skin has been gaining researchers interest in the efforts to obtain alternative gelatine as this commodity can be easily found due to its common consumption by consumers all over the world. This was proven throughout statistics data reported by The United States Department of Agriculture (USDA) where the global poultry production was 111,000 thousand metric tons in 2015 and predicted to increase by $24 \%$ over the next decades, reaching 131,255 thousand metric tons in 2025 ("Global Industry Statistics, Poultry Hub", 2018). Therefore numerous studies have been developed regarding this poultry by which almost all part of that animal has been exploited recently including feet part (Lee et al., 2015), skin part (Sarbon et al., 2015; Nor et al., 2017; Soo and Sarbon, 2018) and also its meat residue (Rammaya et al., 2012) despite the consumption of its meat and eggs.

Currently, rapid progress on the development of gelatine sources from skin and bones derived from poultry underway have been spotted as these sources never had a problem with health issue regarding mad cow diseases caused by bovine spongiform encephalopathy, BSE. Concerning the abundant amount of chicken waste linearly contributed by the high consumption number of chicken from time to time, chicken skin based gelatine have been highlighted and studied by Sarbon et al. $(2013 ; 2015)$ before followed by Nazmi et al. (2017) and Nor et al. (2017) with further application in food packaging area. By examining the functionalities of this type of gelatine by Sarbon et al. (2013), it found that gel strength from chicken gelatine has significantly higher bloom value compared with bovine gelatine due to the intrinsic characteristic such as protein chain composition, molecular weight distribution, amino acid content and types of extraction treatment as well as the properties of collagen.

\subsection{Potential of gelatine base film}

The use of gelatine to form films or coatings was very well studied in the 1960's, which resulted in many patents being filed, mainly in the pharmaceutical area (Park et al., 2008). However, gelatine has again attracted much attention from researchers in recent years as packaging films and coatings due to its natural abundance, renewable, relatively low cost, 
biodegradability, film-forming ability and excellent functional properties (Jahit et al., 2016). The $\alpha-, \beta-, \gamma-$ chains and other peptide fragments of gelatine enable it to be an ideal dispersing and film-forming agent by holding the native hydrophilic and hydrophobic domains in the structure (Ahmad et al., 2015). Due to the existence of reactive functional groups include -NH2, $\mathrm{COOH}$, and $-\mathrm{OH}$ along the backbone and side chains, gelatine can be further blended with other functional polymeric molecules to form composite film with better functional properties (Nur Hanani et al., 2012; Ahmad et al., 2015).

Properties of gelatine films vary depending on both the gelatine type and concentrations used. The functional properties of gelatine film are influenced by different types of gelatine (Nur Hanani et al., 2012), as their physical and structural properties of gelatine are mainly influenced by the molecular weight distribution and amino acid composition (Gómez-Guillén et al., 2009). The study of Nur Hanani et al. (2012) revealed that high concentration gelatine films had good mechanical properties as well as good gas barrier properties. Gelatine film also thin, flexible and possess high optical properties with higher degree of transparency (Jahit et al., 2016; Nur Hazirah et al., 2016). However, gelatine films have some major limitations due to their high moisture sensitivity, high brittleness as well as poor thermal stability (Arvanitoyannis et al., 1998; Nur Hazirah et al., 2016). However, gelatine film possesses poor water vapour barrier and water-resistant due to its high amount of hydrophilic amino acids with negligible or no sulfur containing amino acids (Hoque et al., 2011). Therefore, several research studies have been conducted to improve the functionality of gelatine films by blending and/or mixing with other biopolymers, plasticizers, crosslinking agent, strengthening agents or additives with antimicrobial or antioxidant properties (Al-Hassan and Norziah, 2012; Nur Hanani et al., 2012; Ramos et al., 2016, Said and Sarbon, 2019).

\section{Nanotechnology}

Nanotechnology is a revolutionary field of micro manufacturing involving chemical and physical changes to produce nano-sized material. The word 'nano' is a Latin word meaning 'dwarf'. Currently, this technology has increasingly been considered an attractive field that has revolutionized in various industrial areas like agriculture, food, medicine and etc. It is a technology that involves designing, synthesis and characterization of material (molecule or atom) structure by controlling the sizes and shapes on the nanometre scale. Gupta et al. (2016) and Rai et al. (2009) state that these materials have a unique properties, unlike their macroscale counterparts due to the changes in the high surface to volume ratio and other novel physicochemical properties like appearance, colour, optical, texture, strength, solubility, diffusivity, thermodynamic and etc. Therefore, nanotechnology offers a huge possibility and opportunity for the development and application for solving obstacles ranging from food packaging, pharmaceutical industry, medical, to electronics and energy industry or system with new and unique properties (Omanović-Mikličanin et al., 2019). Nowadays, nanotechnology has carried new industrial revolution and both developed and developing countries are interested in participating more in this adaptable and sustainable technology (Qureshi et al., 2012; Singh et al., 2017).

\subsection{Nanotechnology in food packaging}

The food industry is growing rapidly in line with the increasing number of human in the world. Referring to the United Nation (2017) report, the world's population has reached 7.6 billion by mid-2017 and the world population is projected to increase by more than one billion people within the next 13 years, reaching 8.6 billion in 2030, and to increase further to 9.8 billion in 2050. Thus, the demand for food also increased and that's why researchers want a diversity of methods, technologies and innovations to meet the needs of huge populations demand. Currently, the food packaging sector became the most of nanotechnology applications in the food industry (Reig et al., 2014). This is mainly due to the vast development of nanotechnology in this sector, to a higher acceptance by the consumer of the use of this technology in food packaging rather than in food as ingredients. Moreover, based on the requirements of regulations, application in packaging is less restrictive than for the enforced current food legislation. All of these contributes to the fact that there are many more applications in this area compared to the others food sector, together with the necessity of lighter, stronger, sustainable, efficient and intelligent packages. These packages would be able to provide safe products with superior quality and at the same time can maintaining the food products in the best possible conditions and with a longer shelf-life.

Generally, the functions of packaging are numerous and not only as protecting or preserving of raw or processed food against spoilage or pathogen microorganism, but it also provides as a barrier in controlling potentially damaging levels of light, oxygen and water. It facilitates ease of use, offers adequate storage, conveys information and provides evidence of possible product tampering. Currently, a desirable 
packaging material must have gas and moisture permeability combined with light but have a good strength and biodegradability capabilities (Couch et al., 2016). Thus, nano-based 'smart' or 'intelligent' and 'active' food packaging confer several advantages over conventional packaging methods from providing better packaging material with improved mechanical strength, barrier properties, antimicrobial films to nanosensing for spoilage or pathogen detection and alerting consumer to the safety status of foodstuff (Mihindukulasuriya and Lim, 2014).

A wide variety of nano-materials or nanocomposite from organic and inorganic such as protein, carbohydrate, chitosan, silver nanoparticle, titanium nitride nanoparticle, nano-zinc oxide and nanoclay are introduced as functional additives to food packaging system (Tager, 2014). Application of nanotechnology in food packaging system can be divided into three main categories as i). improve packaging: Nanoparticles are mixed with polymer chain to improve the gas barrier properties, as well as, humidity and temperature resistance of packaging; ii). Active packaging: The use of nanomaterials is helpful to interact directly with food or environment to allow better protection of the food product. Several nanomaterials such as nanosilver, carbon nanotubes and nano magnesium oxide can provide antimicrobial properties; iii). Intelligent/smart packaging: The use of nanoparticles is to design and help in sensing the biochemical or microbial changes in the food. It can detect specific pathogen developing in the food or specific gases from food spoiling. Some smart packaging has been developed to use as tracing devices for food safety (Pal, 2017).

The applications of nanoparticles are not limited to antimicrobial food packaging but have been actively used in food packaging to provide a barrier from mechanical shock or external hazards and protect from extreme thermal to extending shelf-life in the form of nanocomposite and nanolaminates. Application of nanotechnology also can be used in coatings or labels of packaging that providing information about the traceability and tracking of the outside as well as inside food products conditions through the whole food chain. Some example of these application are: temperature variations (freeze-thaw-refreezing, monitoring of cold chain by means of silicon with nanopores structure); leak detection for food that packed under vacuum or modified atmosphere (some compounds change of colour, therefore warming to the consumers that air has come inside due to the leaking problem) (Mills and Hazafy, 2009); humidity changes or foodstuffs being deteriorate or spoil (unusual microbial presence). Liu et al. (2007) state that these sensors work producing a specific pattern of answer against each type of microorganism. In this way, the incorporation of nanoparticles into packaging materials contributes to the best quality foodstuff with longer shelf-life and solves environmental problems by reducing the necessity of using plastics that manage to aid the worldwide waste issue. With all the benefits provided, attempts should be made to develop low-cost packaging by using nanotechnology. The packaging applications along with the most commonly used type of nanomaterial in each situation are briefly described in Table 1.

\section{Food safety}

\subsection{Gelatine based film with antimicrobial property}

The rapid development in the food packaging industry is in line with the diversity of foods that have been created and produced. The use of food packaging is subject to the functionality of the wrapper itself in protecting foods from physical, chemical, or biological damage. Instead of the conventional packaging that offer the single layer with Low-density polyethylene (LDPE) or Ethylene vinyl alcohol (EVOH) and composite package (LDPE/EVOH), development of antimicrobial packaging system that works against moisture, gas and microbial barrier is very useful approach to achieve the mentioned function (Lu et al., 2018).

Antimicrobial packaging is classified under active packaging that prevents surface growth of pathogenic microorganisms in food by the use of antimicrobial agents. The antimicrobial agents incorporated with the inner layer of the packaging will release into food

Table 1. Applications and characteristic of nanomaterial-based food packaging

\begin{tabular}{lll}
\hline \multicolumn{1}{c}{ Application } & \multicolumn{1}{c}{ Type of Nanomaterial } & \multicolumn{1}{c}{ Characteristic } \\
\hline $\begin{array}{l}\text { Mechanical properties } \\
\text { Barrier properties }\end{array}$ & Carbon nanotubes & $\begin{array}{l}\text { A relatively low loading can improve polymer properties without } \\
\text { impact on density, transparency and few other properties. }\end{array}$ \\
Antimicrobial activity & Silver nanoparticles & $\begin{array}{l}\text { Improved gas-barrier and protect against visible and UV light. } \\
\text { Biocidal action based on size and shape-dependent interaction with } \\
\text { microorganisms. }\end{array}$ \\
Active packaging & Inorganic nanoparticles such as iron & $\begin{array}{l}\text { Oxidation of iron instead of food constituents such as myoglobin in } \\
\text { meat products. } \\
\text { Intelligent packaging }\end{array}$ \\
\hline
\end{tabular}

Adapted from Tsagkaris et al. (2018) 
surface during storage and distribution. It prevents the degradation of packaged food which providing protection against microorganisms and therefore, maintain the quality of the food products. According to Suppakul et al. (2003), the lag phase will be extended and the growth rate of microorganisms is reduced which then extending shelf life and maintaining product quality and safety. Table 2 shows the application of antimicrobial packaging done by a few researchers.

Normally, antimicrobial agents such as spices, chitosan, enzymes, bacteriocins and organic acids may be coated, incorporated, immobilized, or surface modified onto packaging materials has been tested with a different result (Gautam and Kumar, 2017). In a study carried out by Lopez-Carballo et al. (2008), an antimicrobial photo sensitizer-containing edible films and coatings based on gelatine as the polymer matrix, incorporating sodium magnesium chlorophyllin (E-140) and sodium copper chlorophyllin (E-141) showed the inhibiting effect towards Staphylococcus aureus and Listeria monocytogenes with reduction of $5 \operatorname{logs}$ and 4 logs respectively. Fernández et al. (2009) found that silver nanoparticles in fluff pulp and nanostructured Lyocell fibres which are immersed in silver nitrate effective against Escherichia coli and S. aureus. Many researchers found that silver nanoparticles have antimicrobial activity towards Gram-negative and Grampositive bacteria and fungi (Hoffmann et al., 2019).

This revealed that silver-based nanotechnology is potentially used as antimicrobial packaging. According to Yadav et al. (2019), silver (Ag) usually incorporated with other materials and served as a nanofiller in food packaging to give antibacterial properties. Kim et al. (2011) investigated the utilization of antimicrobial nanoparticle incorporated into polymer matrix towards pathogenic bacteria as well as factor contributed to the quality of food product such as odour. Chitosan biopolymer films (CBFs) with different viscosities of chitosans were used in this study. The researchers found that CBFs were more effective for inhibition of $L$. monocytogenes as compare to Salmonella enterica serovar Typhimurium and E. coli O157: H7. Li et al. (2012) reviewed on the effectiveness of antimicrobial activity of films which are PLA (polymer 4060D) +AIT (essential oil component of cruciferous plants) and Chitosan + AIT against $S$. enterica serovar Stanley. The microbial growth was reduced from 4.57 to 4.04 and from 4.35 to $4.15 \log$ cycles for PLA +AIT and chitosan + AIT coatings, respectively. However, direct addition of AIT into foods may significantly decrease its antimicrobial activity. In addition, Aguirre et al. (2013) reported on carvacrol and thymol in biodegradable and edible packaging film that was plasticized with glycerol. The used of $1 \%(\mathrm{w} / \mathrm{w})$ oregano EO including carvacrol and thymol effective in controlling gram-positive $S$. aureus compared to gram-negative such as E. coli and Pseudomonas aeruginosa that were tested in their study. In other findings, Singh et al. (2015) revealed that nisin and eugenol oil combination which incorporated into bioactive chitosan film (BAC) showed a potent antimicrobial additive for food applications.

\subsection{Safety of Bio-nano composite}

Replacement of petroleum-based non bio-degradable plastics with biodegradable packaging material sounds to be very important for future application in order to protect human health. The major risk linked with nanosized components is their potential adverse health effects contributed by its migration into the food (Echegoyen and Nerin, 2013). In certain cases, nanoparticles indicated that vascular disease, intracellular damages and pulmonary inflammation can be induced. Since many nanomaterials are not fully discovered and understood,

Table 2. The application of antimicrobial packaging.

\begin{tabular}{|c|c|}
\hline Material used & Application \\
\hline $\begin{array}{l}\text { Chlorophyllins incorporated into the gelatine film- } \\
\text { forming solution }\end{array}$ & $\begin{array}{l}\text { Inhibiting effect of the cast films that reduced the } \\
\text { growth of Staphylococcus aureus and Listeria } \\
\text { monocytogenes. }\end{array}$ \\
\hline $\begin{array}{l}\text { Silver nanoparticles in fluff pulp and nanostructured } \\
\text { Lyocell fibres which were immersed in silver nitrate }\end{array}$ & Effective on Escherichia coli and S. aureus. \\
\hline Chitosan biopolymer films (CBFs) & $\begin{array}{l}\text { Effective inhibition towards L. monocytogenes rather } \\
\text { than Salmonella enterica serovar Typhimurium and Kim et al. (2011) } \\
\text { E. coli O157: H7. }\end{array}$ \\
\hline $\begin{array}{l}\text { PLA(polymer 4060D) +AIT(allyl isothiocyanate) and } \\
\text { Chitosan + AIT }\end{array}$ & Reduction effect on S. enterica serovar Stanley. \\
\hline $\begin{array}{l}\text { Carvacrol and thymol in biodegradable and edible } \\
\text { packaging film that was plasticized with glycerol }\end{array}$ & $\begin{array}{l}\text { Used of } 1 \%(\mathrm{w} / \mathrm{w}) \text { oregano EO including carvacrol } \\
\text { and thymol effective in controlling gram-positive } S \text {. } \\
\text { aureus compared to gram-negative (E. coli and Aguirre et al. (2013) } \\
\text { Pseudomonas aeruginosa). }\end{array}$ \\
\hline Bioactive chitosan film (BAC) & $\begin{array}{l}\text { Revealed that nisin and eugenol oil combination } \\
\text { showed a potent antimicrobial additive for food Singh et al. (2015) } \\
\text { applications. }\end{array}$ \\
\hline
\end{tabular}


the toxicological study is required to clarify the risks involved and food regulation should be established (Mihindukulasuriya and Lim, 2014). Moreover, European act and FDA regulations are already setting the permitted levels of the nanoparticles in food (Chaudhry et al., 2008). In line with that concern, lately, many researchers conducted a study on the effect of nano packaging especially related to food and the impact on regulations.

Li et al. (2008) reported that titanium dioxide $\left(\mathrm{TiO}_{2}\right)$ is not categorized as toxic mineral particles and widely used in drug, cosmetics and food. Nano- $\mathrm{TiO}_{2}$ shows specific characteristics but with unknown risks on human health. It's showed that the erythrocytes treated with nanoTiO $\mathrm{Ti}_{2}$ underwent abnormal sedimentation, hemagglutination and dose-dependent hemolysis which were totally different from those treated with micro$\mathrm{TiO}_{2}$. Their findings suggest that nano-TiO2 may toxic and effected human health. In the near future, about 10 and 100 times of nanosilver of sewage treatment plants are estimated to be released (Mueller and Nowack, 2008). Another few reports related to nanoparticles that show significant influences on aquatic microorganisms that impact to fish reported by Handy et al. (2008) who established evidence of toxicity. The Titanium dioxide nanoparticles are present in the viscera and gills of fish as reported by Zhang et al. (2007). In another study, Sawosz et al. (2007) found that $25 \mathrm{mg} / \mathrm{kg}$ of silver nanoparticles in drinking water exposed to quails affected gastrointestinal microflora.

de Abreu et al. (2010) simulated many types of food and highlighted on the migration of caprolactam, 5chloro-2-(2,4-dichlorophenoxy)phenol (triclosan) and trans,trans-1,4-diphenyl-1,3-butadiene (DPBD) from polyamide and polyamide-nanoclays. Those substances were migrated from matrix polymer into food found to be slow down up to six times with the presence of polymer nanoparticles. Certain nanoparticles will affect some organ that was studied which indicated the spreading of nanoparticles into the reproductive system, testis and brain. The potential migration of nanoparticles also will be a specific concern of brain and unborn foetus (Silvestre et al., 2011). The health effect on other particles incorporated or coated to food packaging is still under study such as $\mathrm{ZnO}$ nanoparticles (Lin and Xing, 2008) and fullerenes (Xia et al., 2010).

\section{Cost opportunity}

\subsection{Waste management in Malaysia}

Waste management has become one of serious concern in Malaysia. The traditional approaches to reducing waste management which is reduce, recycle, and reuse $(3 \mathrm{R})$ method are practised but at the low to moderate levels due to the lack of policy and participation from the public. Private sectors were encouraged to participate in green technology. The Ministry of Energy, Green Technology and Water has given serious concern towards minimizing waste management. The ministry determination in dealing the global environmental change has been carried out by promoting the more environmentally sound waste management (Sreenivasan et al., 2012).

\subsection{Economic perspective}

Actions are necessary and urgent throughout food systems on producing more food, moderating demand, reducing waste and improving governance to move towards more sustainable food systems (Godfray and Garnett, 2014). Proper waste management and reduced food waste can save economic resources, lessen negative impacts of food leftover on waste management systems and contribute to food security. The large economic impact of food wastage affects all the individuals and organizations involved in the food supply chain. Saving money can be a driving factor to prevent food waste behaviours; therefore, people need to understand the economic costs of food wastage that can occur when they do so (Quested et al., 2013; Graham-Rowe et al., 2014; Waste Minz, 2014).

Research has shown that the higher the incomes of household, the more varied diet they will consume (Drewnowski, 1999; Pingali and Khwaja, 2004; French et al., 2019). In developed countries, people eat more protein, energy-rich and convenience foods, and eat less rice. For example, western foods that have shorter shelflife foods and more vulnerable may lead to greater food waste (Lundqvist et al., 2008). Conrad et al. (2018) stated that the food will be less wasted in the more repetitive diet rather than a diversified diet. Hence in restaurants, spread menus will lead to more food waste since there are extra ingredients to manage.

\subsection{Business opportunities for fishbone and poultry waste}

Previously, seafood and poultry waste business is not popular among the entrepreneur. Due to low economic value, seafood and poultry waste were thrown out as waste or leftover as organic fertiliser. Moreover, there are only a few available proven processing technologies exhibited by industrial players that contribute to the underdevelopment of the seafood and poultry waste industry. In addition, financial institutions also have a low confidence level towards most seafood and poultry investor due to the lack of mature technologies that will lead to unsuccessful financing support. 
Industrialization of food systems will affect the foods that people eat, contributes to increasing the types and quantities of food waste (Parfitt et al., 2010). The food production and preparation has been shifted from home to factory and also from cooking to buying (Strasser, 1999). For example, in industrialized food systems, people will purchase pre-cut meats, such as chicken legs. Thus, there are no other parts of the chicken to be wasted because the other parts of the chicken are utilized by industry during the chicken processing. Therefore, these seafood and poultry waste can be good business opportunities for industry player and entrepreneur.

Waste to wealth should be applied among the consumer in order to reduce the global warming phenomenon from seafood and poultry waste toward sustainable waste management. For instance, the commercial fish processing industry generates a problem when only flesh is used to make a product and a huge number of unwanted parts will be dumped as waste. Fish waste has active ingredients that can produce a high value product. Collagens are among others the example of the product that can be extracted from seafood waste and widely used in the pharmaceutical field (Raghuraman et al., 2013). Without proper utilization of waste, environmental problems might occur. The fish waste was testified as a good source of protein content and polyunsaturated lipid. Active ingredients that present in food waste can create natural product such as proteins, polysaccharides, fibres, flavour compounds, and phytochemicals have shown potential market (Baiano, 2014).

\section{Conclusion}

In conclusion, the recent development of nanocomposite technology has provided renewed opportunities for the use of gelatine-based nanocomposite films in the food packaging industry. Gelatine films composited with nanofillers, such as nanoclay, organic fillers, and nanometals (like AgNPs, CuNPs, $\mathrm{ZnO} \mathrm{NPs}$ ), and $\mathrm{TiO}_{2} \mathrm{NPs}$, have shown not only improved film properties but also strong antimicrobial activity. However, the properties of gelatine-based nanocomposite films produced are depending on the type of gelatine used. Proper utilization of fish and poultry waste has been proved contributed to the economy through the introduction of high-value products besides generating a solved environmental problem. Thus, the waste to wealth concept applied to the fish and poultry waste can be achieved by focusing on integrating nanoparticles with biopolymers as antimicrobial packaging.

\section{Conflict of Interest}

The authors declare no conflict of interest.

\section{References}

Abdul Aziz, A.N. (2007). Life cycle in vectorization between open dumps and sanitary landfills. Board of Engineers Malaysia, 34, 12-17.

Abushammala, M.F.M., Basri, N.E.A., Basri, H., ElShafie, A.H. and Kadhum, A.A.H. (2011). Regional landfills methane emission inventory in Malaysia. Waste Management and Research, 29(8), 863-873. https://doi.org/10.1177/0734242X10382064

Agamuthu, P., Fauziah, S.H., Noorazamimah, A.A. and Suhaila, M.O. (2006). Recycling of municipal solid waste: is it sustainable? Paper presented at The Green Chemistry Conference, Malaysian Institute of Chemistry, September 19-21. Kuala Lumpur: Malaysian Institute of Chemistry.

Aguirre, A., Borneo, R. and Leon, A.E. (2013). Antimicrobial, mechanical and barrier properties of triticale protein films incorporated with oregano essential oil. Food Bioscience, 1, 2-9. https:// doi.org/10.1016/j.fbio.2012.12.001

Ahmad, M., Norziah, M.H., Nirmal, N.P., Fazial, F.F., Mohtar, N.F. and Romli, S.R. (2015). Optical and thermo-mechanical properties of composite films based on fish gelatine/rice flour fabricated by casting technique. Progress in Organic Coatings, 84, 115127. https://doi.org/10.1016/j.porgcoat.2015.02.016

Al-Hassan, A.A. and Norziah, M.H. (2012). Starchgelatine edible films: Water vapour permeability and mechanical properties as affected by plasticizers. Food Hydrocolloids, 26(1), 108-117. https:// doi.org/10.1016/j.foodhyd.2011.04.015

Arvanitoyannis, I., Nakayama, A. and Aiba, S. (1998). Edible films made from hydroxypropyl starch and gelatine and plasticized by polyols and water. Carbohydrate Polymers, 36(2-3), 105-119. https:// doi.org/10.1016/S0144-8617(98)00017-4

Baiano, A. (2014). Recovery of biomolecules from food wastes - A review. Molecules, 19(9), 14821-14842. https://doi.org/10.3390/molecules190914821

Benhabiles, M.S., Abdi, N., Drouiche, N., Lounici, H., Pauss, A., Goosen, M.F.A. and Mameri, N. (2012). Fish protein hydrolysate production from sardine solid waste by crude pepsin enzymatic hydrolysis in a bioreactor coupled to an ultrafiltration unit. Material Science and Engineering: C, 32(4), 922928. https://doi.org/10.1016/j.msec.2012.02.013

Budhiarta, I., Siwar, C. and Basri, H. (2012). Current status of municipal solid waste generation in Malaysia. International Journal on Advanced 
Science, Engineering and Information Technology, 2 (3), 129-134. https://doi.org/10.18517/ijaseit.2.2.169

Chandra, M.V., Shamasundar, B.A. and Kumar, P.R. (2013). Visco-Elastic and Flow Properties of Gelatine from the Bone of Freshwater Fish (Cirrhinus mrigala). Journal of Food Science, 78(7), 1-8. https://doi.org/10.1111/17503841.12158

Chaudhry, Q., Scotter, M., Blackburn, J., Ross, B., Boxall, A. and Castle, L. (2008). Applications and implications of nanotechnologies for the food sector. Food Additives and Contaminants: Part A: Chemistry, Analysis, Control, Exposure and Risk Assessment, 25(3), 241-258. https:// doi.org/10.1080/02652030701744538

Cheow, C.S., Norizah, M.S., Kyaw, Z.Y. and Howell, N.K. (2007). Preparation and characterisation of gelatine from the skins of sin croaker (Johnius dussumieri) and shortfin scad (Decapterus mascrosoma). Food Chemistry, 101(1), 386-391. https://doi.org/10.1016/j.foodchem.2006.01.046

CIA. (2018). The World Factbook: Malaysia. Retrieved from Central Intelligence Agency website: https:// www.cia.gov/library/publications/the-worldfactbook/geos/my.html

Conrad, Z., Niles, M.T., Neher, D.A., Roy, E.D., Tichenor, N.E. and Jahns, L. (2018). Relationship between food waste, diet quality, and environmental sustainability. PLoS ONE, 13(4), 1-18. https:// doi.org/10.1371/journal.pone.0195405

Couch, L.M., Wien, M., Brown, J.L. and Davidson, P. (2016). Food nanotechnology: proposed uses, safety concerns and regulations. Agro Food Industry $\mathrm{Hi}$ Tech, 27(1), 36-39.

de Abreu, D.A.P., Cruz, J.M., Angulo, I. and Losada, P.P. (2010). Mass transport studies of different additives in polyamide and exfoliated nanocomposite polyamide films for food industry. Packaging Technology Science, 23(2), 59-68. https:// doi.org/10.1002/pts.879

Drewnowski, A. (1999). Fat and sugar in the global diet. In Grew, R. (Ed.). Food in Global History. Boulder, USA: Westview Press.

Duncan, T.V. (2011). Applications of nanotechnology in food packaging and food safety: Barrier materials, antimicrobials and sensors. Journal of Colloid Interface Science, 363(1), 1-24. https:// doi.org/10.1016/j.jcis.2011.07.017

Echegoyen Y. and Nerín, C. (2013). Nanoparticle release from nano-silver antimicrobial food containers. Food Chemistry Toxicology, 62, 16-22. https:// doi.org/10.1016/j.fct.2013.08.014
Eusuf, M.A., Ibrahim, M., Din, S.A.M. and Islam, R. (2011). Solid Waste Generation Characteristics: The Malaysian Local Authorities' Outlook. Journal of the Malaysian Institute of Planners, 6, 51-76. https:// doi.org/10.21837/pmjournal.v9.i2.85

FAO. (2011). Global food losses and food waste Extent, causes and prevention. Rome: FAO.

Farhoodi, M. (2016). Nanocomposite Materials for Food Packaging Applications: Characterization and Safety Evaluation. Food Engineering Reviews, 8(1), 35-51. https://doi.org/10.1007/s12393-015-9114-2

Fernández, A., Soriano, E., Carballo, G.L., Picouet, P., Lloret, E., Gavara, R. and Hernández-Muñoz, P. (2009). Preservation of aseptic conditions in absorbent pads by using silver nanotechnology. Food Research International, 42(8), 1105-1112. https:// doi.org/10.1016/j.foodres.2009.05.009

French, S.A., Tangney, C.C., Crane, M.M. Wang, Y. and Appelhans, B.M. (2019). Nutrition quality of food purchases varies by household income: the SHoPPER study. BMC Public Health, 19, 231. https://doi.org/10.1186/s12889-019-6546-2

Gautam, R.B. and Kumar, S. (2017). Development of Protein Based Films with Nanoparticle as Strengthening Material for Biodegradable Packaging -A Review. International Journal of Agriculture Innovations and Research, 5(5), 790-805.

Global Industry Statistics, Poultry Hub. (2018). Retrieved from Poultry Hub website: http:// www.poultryhub.org/production/industry structure and organisations/global-industry-statistics.

Godfray, H.C.J. and Garnett, T. (2014). Food security and sustainable intensification. Philosophical Transaction of Royal Society B: Biological Sciences, 369, 1639. https://doi.org/10.1098/rstb.2012.0273

Gómez-Guillén, M.C., Perez-Mateos, M., Gomez-Estaca, J., Lopez-Caballero, E., Gimenez, B. and Montero, P. (2009). Fish gelatine: a renewable material for developing active biodegradable films. Trends in Food Science and Technology, 20(1), 3-16. https:// doi.org/10.1016/j.tifs.2008.10.002

Graham-Rowe, E., Jessop, D.C. and Sparks, P. (2014). Identifying motivations and barriers to minimising household food waste. Resources Conservation Recycling, 84, 15-23. https://doi.org/10.1016/ j.resconrec.2013.12.005

Gupta, A., Eral, H.B., Hatton, T.A. and Doyle, P.S. (2016). Nanoemulsions: formation, properties and applications. Soft Material, 12(1), 2826-2841. https://doi.org/10.1039/C5SM02958A

Hadfi, N.H. and Sarbon, N.M. (2019). Physicochemical properties of silver catfish (Pangasius sp.) skin 
collagen as influenced by acetic acid concentration. Food Research, 3(6), 783 - 790. https:// doi.org/10.26656/fr.2017.3(6).130

Halim, N.R.A. and Sarbon, N.M. (2017). A response surface approach on hydrolysis condition of eel (Monopterus Sp.) protein hydrolysate with antioxidant activity. International Food Research Journal, 24(3), 1081-1093.

Halim, N.R.A., Azlan, A., Yusof, H.M. and Sarbon, N.M. (2018). Antioxidant and anticancer activities of enzymatic eel (Monopterus sp.) protein hydrolysate as influenced by different molecular weight. Biocatalysis and Agricultural Technology, 16, 10-16. https://doi.org/10.1016/j.bcab.2018.06.006

Halim, N.R.A., Yusof, H.M. and Sarbon, N.M. (2016). Functional and Bioactive Properties of Fish Protein Hydrolysates and Peptides: A Comprehensive Review. Trends in Food Science and Technology, 51, 24-33. https://doi.org/10.1016/j.tifs.2016.02.007

Hamdan, F.S. and Sarbon, N.M. (2019). Isolation and characterization of collagen from Fringescale sardinella (Sardinella fimbriata) waste materials. International Food Research Journal, 26(1), 133 140.

Handy, R.D., von der Kammer, F., Lead, J.R., Hassellöv, M., Owen, R. and Crane, M. (2008). The ecotoxicology and chemistry of manufactured nanoparticles. Ecotoxicology, 17, 287-314. https:// doi.org/10.1007/s10646-008-0199-8

Heller, M. (2017). Food product environmental footprint literature summary: packaging and waste food. Department of Environmental Quality. Oregon, USA: State of Oregon Department of Environmental Quality.

Hoffmann, T., Amaral Peters D., Angioletti, B., Bertoli, S., Peres Vieira, L., Ratto Reiter, M.G. and Krebs De Souza, C. (2019). Potentials Nanocomposites in Food Packaging, Chemical Engineering Transactions, 75, 253-258.

Hoque, M.S., Benjakul, S., Prodpran, T. and Songtipya, P. (2011). Properties of blend film based on cuttlefish (Sepia pharaonis) skin gelatine. International Journal of Biological Macromolecules, 49(4), 663-673. https://doi.org/10.1016/ j.ijbiomac.2011.06.028

Ishak, N.H. and Sarbon, N.M. (2017). Optimization of the enzymatic hydrolysis conditions of waste from shortfin scad (Decapterus Macrosoma) for the production of angiotensin I-converting enzyme (ACE) inhibitory peptide using response surface methodology. International Food Research Journal, 24(4), 1735-1743.
Ishak, N.H. and Sarbon, N.M. (2018). A Review of Protein Hydrolysates and Bioactive Peptides Deriving from Wastes Generated by Fish Processing. Food and Bioprocess Technology, 11(1), 2-16. https://doi.org/10.1007/s11947-017-1940-1

Jahit, I.S., Nazmi, N.N.M., Isa, M.I.N. and Sarbon, N.M. (2016). Preparation and physical properties of gelatine/ CMC/ chitosan composite films as affected by drying temperature. International Food Research Journal, 23(3), 1068-1074.

Jereme, I.A., Siwar, C., Begum, R.A., Talib, B.A. and Choy, E.A. (2018). Analysis of Household Food Waste Reduction Towards Sustainable Food Waste Management in Malaysia. The Journal of Solid Waste Technology and Management, 44(1), 86-96. https://doi.org/10.5276/JSWTM.2018.86

Johari, A., Alkali, H., Hashim, H., Ahmed, S.I. and Mat, R. (2014). Municipal solid waste management and potential revenue from recycling in Malaysia. Modern Applied Science, 8(4), 37-49. https:// doi.org/10.5539/mas.v8n4p37

Kathirvale, S., Muhd Yunus, M.N., Sopian, K. and Samsuddin, A.H. (2004). Energy potential from municipal solid waste in Malaysia. Renewable Energy, 29(4), 559-567. https://doi.org/10.1016/ j.renene.2003.09.003

Kim, K. W., Min, B. J., Kim, Y.T., Kimmel, R.M., Cooksey, K. and Park, S.I. (2011). Antimicrobial activity against foodborne pathogens of chitosan biopolymer films of different molecular weights. LWT-Food Science and Technology, 44(2), 565-569. https://doi.org/10.1016/j.lwt.2010.08.001

Koli, J.M., Basu, S., Nayak, B.B., Patange, S.B., Pagarkar, A.U. and Gudipati, V. (2012). Functional characteristics of gelatine extracted from skin and bone of Tiger-toothed croaker (Otolithes ruber) and Pink perch (Nemipterus japonicus). Food and Bioproducts Processing, 90(3), 555-562. https:// doi.org/10.1016/j.fbp.2011.08.001

Lassoued, I., Jridi, M., Nasri, R., Dammak, A., Hajji, M., Nasri, M. and Barkia, A. (2014). Characteristics and functional properties of gelatine from thornback ray skin obtained by pepsin-aided process in comparison with commercial halal bovine gelatine. Food Hydrocolloids, 41, 309-318. https://doi.org/10.1016/ j.foodhyd.2014.04.029

Lee, J.H., Lee, J. and Song, K.B. (2015). Development of a chicken feet protein film containing essential oils. Food Hydrocolloids, 46, 208-215. https:// doi.org/10.1016/j.foodhyd.2014.12.020

Li, K.K., Yin, S.W., Yang, X.Q., Tang, C.H. and Wei, Z.H. (2012). Fabrication and characterization of 
novel antimicrobial films derived from thymolloaded zein- sodium caseinate (SC) nanoparticles. Journal of Agriculture and Food Chemistry, 60, 11592-11600. https://doi.org/10.1021/jf302752v

Li, Q., Mahendra, S., Lyon, D. Y., Brunet, L., Liga, M.V., Li, D. and Alvarez, P.J.J. (2008). Antimicrobial nanomaterials for water disinfection and microbial control: Potential applications and implications. Water Resources, 42(18), 4591-4602. https://doi.org/10.1016/j.watres.2008.08.015

Lim, L.Y., Lee, C.T., Bong, C.P.C., Lim, J.S. and Klemeš, J.J. (2019). Environmental and economic feasibility of an integrated community composting plant and organic farm in Malaysia. Journal of Environmental Management, 244, 431-439. https:// doi.org/10.1016/j.jenvman.2019.05.050

Lin, D. and Xing, B. (2008). Root uptake and phytotoxicity of $\mathrm{ZnO}$ nanoparticles. Environmental Science Technology, 42, 5580-5585. https:// doi.org/10.1021/es800422x

Liu, Y., Chakrabartty, S. and Alocilja, E. (2007). Fundamental building blocks for molecular biowire based forward error-correcting biosensors. Nanotechnology, 18(42), 1-6. https:// doi.org/10.1088/0957-4484/18/42/424017

López-Carballo, G., Hernández-Muñoz, P., Gavara, R. and Ocio, M.J. (2008). Photoactivated chlorophyllinbased gelatine films and coatings to prevent microbial contamination of food products International. Journal of Food Microbiology, 126(12), 65-70. https://doi.org/10.1016/ j.ijfoodmicro.2008.05.002

Lu, P., Guo, M., Xu, Z. and Wu, M. (2018). Application of Nanofibrillated Cellulose on OPP/LDPE Film as Oxygen Barrier and Antimicrobial Coating Based on Cold Plasma Treatment. Coatings, 8(6), 1-13. https:// doi.org/10.3390/coatings 8060207

Lundqvist, J., de Fraiture, C. and Molden, D. (2008). Saving Water: From Field to Fork. Curbing Losses and Wastage in the Food Chain. Sweden: SIWI Policy Brief.

Manaf, L.A., Samah, M.A.A. and Zukki, N.I.M. (2009). Municipal solid waste management in Malaysia: Practices and challenges. Waste Management, 29 (11), 2902-2906. https://doi.org/10.1016/ j.wasman.2008.07.015

Mihindukulasuriya, S.D.F. and Lim, L.T. (2014). Nanotechnology development in food packaging: a review. Trends in Food Science and Technology, 40 (2), 149-167. https://doi.org/10.1016/ j.tifs.2014.09.009

Mills, A. and Hazafy, D. (2009) Nanocrystalline SnO2- based, UVB-activated, colorimetric oxygen indicator. Sensors and Actuators B-Chemical, 136 (2), 344-349. https://doi.org/10.1016/ j.snb.2008.12.048

Ministry of Housing and Local Government Malaysia. (2011). Development of a National Strategic Plan for Food Waste Management in Malaysia. Retrieved from website: http://www.uncrd.or.jp/content/ documents/Hanoi\%203R\%20Forum\%

20PS5_Malaysia.pdf

Mueller, N.C. and Nowack, B. (2008). Exposure modeling of engineered nanoparticles in the environment. Environmental Science Technology, 42, 4447-4453. https://doi.org/10.1021/es7029637

Nazmi, N.N., Isa, M.I.N. and Sarbon, N.M. (2017). Preparation and characterization of chicken skin gelatine/CMC composite film as compared to bovine gelatine film. Food Bioscience, 19, 149155. https://doi.org/10.1016/j.fbio.2017.07.002

Nor, M.H.M., Nazmi, N.N.M. and Sarbon, N.M. (2017). Effects of plasticizer concentrations on functional properties of chicken skin gelatine films. International Food Research Journal, 24(5), 19101918.

Nur Hanani, Z.A., Roos, Y.H. and Kerry, J.P. (2012). Use of beef, pork and fish gelatine sources in the manufacture of films and assessment of their composition and mechanical properties. Food Hydrocolloids, 29(1), 144-151. https:// doi.org/10.1016/j.foodhyd.2012.01.015

Nur Hazirah, M.A.S.P., Isa, M.I.N. and Sarbon, N.M. (2016). Effect of xanthan gum on the physical and mechanical properties of gelatine-carboxymethyl cellulose. Food Packaging and Shelf Life, 9, 55-63. https://doi.org/10.1016/j.fps1.2016.05.008

Omanović-Mikličanin, E., Badnjević, A., Kazlagić, A. and Hajlovac, M. (2019) Nanocomposites: a brief review. Health and Technology, 2019, https:// doi.org/10.1007/s12553-019-00380-x

Pal, M. (2017). Nanotechnology: A New Approach in Food Packaging. Journal of Food, Microbiology, Safety and Hygiene, 2(2), 1000121. https:// doi.org/10.4172/2476-2059.1000121

Parfitt, J., Barthel, M. and Macnaughton, S. (2010). Food waste within food supply chains: quantification and potential for change to 2050. Philosophical transactions of the Royal Society of London. Series B, Biological Sciences, 365, 1554. https:// doi.org/10.1098/rstb.2010.0126

Park, J.W., Whiteside, W.S. and Cho, A.Y. (2008). Mechanical and water vapor barrier properties of extruded and heat-pressed gelatine films. LWT - 
Food Science and Technology, 41(4), 692-700.

Periathamby, A., Hamid, F.S. and Khidzir, K. (2009). Evolution of solid waste management in Malaysia: impacts and implications of the solid waste bill, 2007. Journal of Material Cycles and Waste Management, 11(2), 96-103. https://doi.org/10.1007/ s10163-008-0231-3

Pingali, P. and Khwaja, Y. (2004). Globalisation of Indian Diets and the Transformation of the Food Supply Systems. In ESA Working Paper No. 04-05, Retrieved from:http://www.eldis.org/vfile/upload/1/ document/0708/doc15357.pdf accessed28.08.15).

Quested, T.E., Marsh, E., Stunell, D. and Parry, A.D. (2013). Spaghetti soup: the complex world of food waste behaviours. Resources Conservation Recycling, 79, 43-51.

Qureshi, A.M., Swaminathan, K., Karthikeyan, P., Ahmed, K.P., Sudhir, and Mishra, U.K. (2012). Application of nanotechnology in food and dairy processing: an overview. Pakistan Journal of Food Science, 22(1), 23-31.

Raghuraman, H. (2013). Extraction of sulfated glycosaminoglycans from mackerel and herring fish waste. Halifax, Nova Scotia, Canada: Dalhousie University, MSc. Thesis

Rai, M., Yadav, A. and Gade, A. (2009). Silver nanoparticles as a new generation of antimicrobials. Biotechnology Advances, 27(1), 76-83.

Rammaya, K., Voon, Q.Y. and Babji, A.S. (2012). Physicochemical analysis of gelatine extracted from mechanically deboned chicken meat residue. International Journal of Food, Nutrition and Public Health, 5(1/2/3), 147-168.

Ramos, M., Arantzazu, A., Beltran, A. and Garrigos, M.C. (2016). Review: gelatine-based films and coatings for food packaging applications. Coatings, 6(4), 41. https://doi.org/10.3390/coatings6040041

Rasli, H.I. and Sarbon, N.M. (2018). Optimization of enzymatic hydrolysis condition and characterization of Shortfin scad (Decapterus Macrosoma) skin gelatine hydrolysate by using Response Surface Methodology (RSM). International Food Research Journal, 25(4), 1541-1549.

Rasli, H.I. and Sarbon, N.M. (2019). Preparation and physicochemical characterization of fish skin gelatine hydrolysate from shortfin scad (Decapterus macrosoma). International Food Research Journal, 26(1), $287-294$.

Razali, F., Weng Wai, C. and Daud, D. (2019) A Review of Malaysia Solid Waste Management Policies to Improve Recycling Practice and Waste Separation Among Households. International Journal of Built
Environment and Sustainability, 6(1-2), 39-45. https://doi.org/10.11113/ijbes.v6.n1-2.381

Reig, C.S., Lopez, A.D., Ramos, M.H. and Ballester, V.A.C. (2014). Nanomaterials: a Map for Their Selection in Food Packaging Applications. Packaging Technology and Science, 27(11), 839866. https://doi.org/10.1002/pts.2076

Rosli, N. and Sarbon, N.M. (2015). Physicochemical and structural properties of eel (Monopterus sp.) skin gelatine as compared to bovine gelatine. International Food Research Journal, 22(2), 699706.

Saheri, S., Aghajani, M., Basri, N.E.A., Mahmod, N.Z.B. and Begum, R.A. (2011). Environmental assessment of municipal solid waste disposal options in Malaysia. Australian Journal of Basic and Applied Sciences, 5(11), 1069-1073.

Sahu, B.B., Barik, N.K., Agnibesh, A., Paikaray, A., Mohapatra, S., Senapati, S., Das, K.C. and Sundaray, J.K. (2017). Recycled fish processing waste for welfare of aquaculture industry: A review. International Journal of Fisheries and Aquatic Research, 2(2), 37-42.

Said, N.S. and Sarbon, N.M. (2019). Response surface methodology (RSM) of chicken skin gelatine based composite films with rice starch and curcumin incorporation. Polymer Testing, 81, 106161. https:// doi.org/10.1016/j.polymertesting.2019.106161

Sarbon, N.M., Badii, F. and Howell, N.K. (2013). Preparation and characterisation of chicken skin gelatine as an alternative to mammalian gelatine. Food Hydrocolloids, 30(1), 143-151. https:// doi.org/10.1016/j.foodhyd.2012.05.009

Sarbon, N.M., Badii, F. and Howell, N.K. (2015). The effect of chicken skin gelatine and whey protein interactions on rheological and thermal properties. Food Hydrocolloids, 45, 83-92. https:// doi.org/10.1016/j.foodhyd.2014.10.008

Sawosz, E., Binek, M., Grodzik, M., Zielinska, M., Sysa, P., Szmidt, M., Niemiec, T. and Chwalibog, A. (2007). Influence of hydrocoloidal silver nanoparticles on gastrointestinal microflora and morphology of enterocytes of quails. Archives of Animal Nutrition, 61(6), 444-451. https:// doi.org/10.1080/17450390701664314

Sharma, D. and Dhanjal, D.S. (2016). BioNanotechnology for Active Food Packaging. Journal of Applied Pharmaceutical Science, 6(9), 220-226. https://doi.org/10.7324/JAPS.2016.60933

Silvestre, C., Duraccio, D. and Cimmino, S. (2011). Food packaging based on polymer nanomaterials. Progress in Polymer Science, 36(12), 1766-1782. 
https://doi.org/10.1016/j.progpolymsci.2011.02.003

Singh, T., Shukla, S., Kumar, P., Wahla, V., Bajpai, V.K. and Rather, I.A. (2017). Application of Nanotechnology in Food Science: Perception and Overview. Frontiers in Microbiology, 8, 1501. https://doi.org/10.3389/fmicb.2017.01501

Singh, T.P., Chatli, M.K. and Sahoo, J. (2015). Antimicrobial Activity of Chitosan Based Bioactive Film Incorporated with Nisin and Eugenol. Journal of Veterinary and Public Health, 13(1), 59-62.

Soo, P.Y. and Sarbon, N.M. (2018). Preparation and characterization of edible chicken skin gelatine film incorporated with rice flour. Food Packaging and Shelf Life, 15, 1-8. https://doi.org/10.1016/ j.fpsl.2017.12.009

Sreenivasan, J., Govindan, M., Chinnasami, M. and Kadiresu, I. (2012). Solid waste management in Malaysia: a move towards sustainability. In Rebellon, L.F.M. (Ed.) Waste management: an integrated vision., p. 55-70. InTech E-book. https:// doi.org/10.5772/50870

Strasser, S. (1999). Waste and Want: A Social History of Trash. New York, USA: Metropolitan Book Henry Holt.

Suppakul, P., Miltz,J., Sonneveld, K. and Bigger, S.W. (2003). Active Packaging Technologies with an Emphasis on Antimicrobial Packaging and its Applications. Journal of Food Science, 68(2), 408420. https://doi.org/10.1111/j.13652621.2003.tb05687.x

Tager, J. (2014). Nanomaterials in food packaging: FSANZ fails consumers gain. Retrieved from Friends of the Earth. Emerging Tech Project website: http://emergingtech.foe.org.au/nanomaterials-in-food -packaging-fsanz-fails-consumers-again/

Wangtueai, S. and Noomhorm, A. (2008). Processing optimization and characterization of gelatine from lizardfish (Saurida spp.) scales. LWT-Food Science and Technology, 42(4), 825-834. https:// doi.org/10.1016/j.lwt.2008.11.014

Waste Minz. (2014). National Food Waste Prevention Study. Waste Minz, Auckland, New Zealand, Retrieved on October 23, 2015 from Waste Minz website: http://www.wasteminz.org.nz/sectorgroups/behaviour-change/national-food-wasteprevention-project/ (accessed23.10.15).

Xia, X.R., Monteiro-Riviere, N.A. and Riviere, J.E. (2010). Skin penetration and kinetics of pristine fullerenes (C60) topically exposed in industrial organic solvents. Toxicology and Applied Pharmacology, 242(1), 29-37. https:// doi.org/10.1016/j.taap.2009.09.011
Yadav, M., Liu, Y. and Chiu, F. (2019). Fabrication of Cellulose Nanocrystal/Silver/Alginate Bionanocomposite Films with Enhanced Mechanical and Barrier Properties for Food Packaging Application. Nanomaterials, 1523(9), 1-19. https:// doi.org/10.3390/nano9111523

Zhang, X., Sun, H., Zhang, Z., Chen, Y. and Crittenden, J. (2007). Enhanced bioaccumulation of cadmium in carp in the presence of titanium dioxide nanoparticles. Chemosphere, 67(1), 160-166. https:// doi.org/10.1016/j.chemosphere.2006.09.003 